\title{
Article
}

\section{What If Imagination Were Real?}

\section{Risk and Potentiality in Copenhagen-based Performance Art Examples}

\author{
Maja Ejrnæs \\ University of Copenhagen/Sisters Hope
}

\begin{abstract}
This article explores extremity in performance art from the perspective of an insider. The article contributes with ethnographic insights on liminality and lived experience in performance art, which is still an unexplored field of anthropological study. It investigates how the Copenhagen-based performance group called Sisters Hope intentionally evoke examples of (and for) a future Sensuous Society. It argues that framing is key to what Sisters Hope examples evoke and whether they 'work' as intended; as transformative counterparts to 'the outside world'. While extremity may take on the appearance of shocking contrasts, it is also emphasized as a matter of blurry boundaries in the selected performance art examples. In this context, extremity is cast as radical risk and potentiality that shake or transform experienced reality. The paper argues that Sisters Hope participants navigate in what if modes where sensations in the present and hopes for the future overlap in utopian performatives here and now. Through engagement with performance art examples over time, pretend play can transform into experienced authenticity, and this may eventually reverse experiences of what is ordinary and extreme for the immersed participant. The paper ends with a contemplation on whether the transformative impact of performance art examples is limited by societal fear of the unknown.
\end{abstract}

\section{Keywords}

performance art, performativity, liminality, example, extreme, framing, matter, evocation 


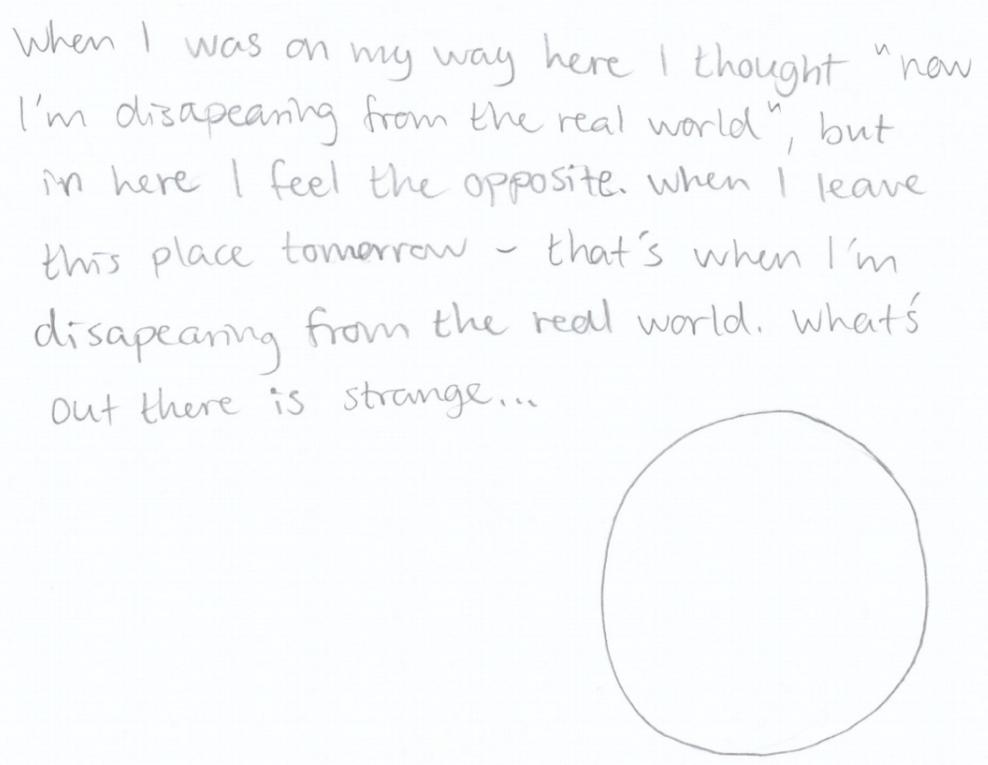

Does performance art matter? And if so, how? The handwritten reflections above appear in a notebook from a participant in a sensuous boarding school for adults that took place in 2015 as part of the large-scale performance art project called Sisters Academy. Most participants were positioned as Students and equipped with personal notebooks, which they 'donated' to The Archive after a minimum 24 hours stay. Sisters Academy is often portrayed as a parallel dream world in press coverage (cf. Chukri 2015; Krøjby 2017). But the reflections above suggest that the writing participant found a heightened realness, which, to the contrary, made the world 'out there' seem strange. By conveying a sense of reality turned upside down, the quote is an apt outset for further inquiry into the field of live performance art.

Performance art is a fluid, contested, and broad-ranging genre that has developed in parallel with practice-oriented performance studies, partly influenced by ritual theory and closely associated with movements such as site-specific, happenings, and body art (Carlson [1996] 2004, 110; Kirshenblatt-Gimblett [2004] 2016). Ethnographic literature on performance art is scarce, despite the fact that the performative turn and representational debate in the second half of the $20^{\text {th }}$ century spurred anthropological interest in performativity and studies of social events as performance (Schechner [2013] 2017, 30) - along with concepts such as performance, roles, play, frame, speech-act, social drama, front- and backstage. If we return to The Student's quote, the circle below the writing may help us ascertain the blurry matter at stake in performance art. Personally, I do not know if the (anonymous) Student had a particular reason for drawing the circle, but both the circle and its undefined nature relate to my understanding of performance art practice. In particular, I associate the circle with a ritual that I designed a couple of years ago, which may serve as an example to guide the reader's imagination. In the ritual, I draw circles with charcoal on large parchment paper; I draw the same circle in an uneven repetitive manner without lifting the charcoal from the paper. 
As such, the ritual mimics the idea of performativity as citationality, where matter materializes through continuous iterations (Butler 1993, 12-13). The circle thickens through each repeated circular drawing, constantly changing, as I am unable to repeat the exact circular movement from before. Participants have engaged in the ritual by sitting close by and afterwards articulated experiences of meditative states or recalled childhood memories. The ritualized circle drawing is further a sensory matter; dry, scratching, and screeching sounds of friction between paper and charcoal, small explosions of charcoal splinters that resemble sparks from a fireplace, along with changing sensations of pain from holding onto the charcoal and pressing against the paper. While the latter is my own experience, it is traceable and thus also part of an intersubjective field of both shared and disconnected associations (Fischer-Lichte 2008, 143). While the circle becomes more and more real through the drawing, it might eventually disappear in a black hole of charcoal. Following on from the circular drawing, I do not begin this article with a clear-cut definition of performance art, but I hope to offer a better understanding of the matter at stake though ethnographic evocation of repetitive (circular) patterns in the field.

The article is based on an insider ethnography of a Copenhagen-based performance art group called Sisters Hope. The name 'Sisters' derives from a collaboration between Gry Worre Hallberg and Anna Lawaets, who started the initiative as 'poetic twin sisters' in 2007 (Hallberg 2016, 37). Sisters Hope was initially presented as a parallel universe and learning method based on live and relational performance art (Hallberg and Lawaetz 2011). Sisters Academy then evolved as a radical performance and educational experiment to democratize 'the aesthetic dimension', grounded in Herbert Marcuse's idea that art has liberating potential in world, which has been dominated by rational and economic principles since Enlightenment (Krøgholt, Hallberg, and Lawaetz 2013, 95; Marcuse 1979). In direct response to the economic crisis of 2008, Hallberg formulated The Sensuous Society manifesto as a vision towards a more poetic and sensuous future society, where everyone can access aesthetic experiences (The Sensuous Society 2020). Since 2014, Gry Worre Hallberg has been The Sister and artistic director of a performer group, which primarily consists of Danish women in their 20s and 30s with backgrounds in art. In the rest of the article, I will primarily use the artistic director's forename Gry, and refer to Sisters Hope as a group that shares a performance practice. Personally, I have been engaged in the group as a performer, researcher, and teacher since 2015, when I started as a study-related intern in the project. This article is based on ethnographic material from my master's thesis as well as accounts from other projects, when I was not intentionally doing fieldwork.

Performance art has a general reputation of being extreme. Sisters Hope projects are often associated with words such as extreme, radical, unknown or mysterious by participants as well as in the press (cf. Chukri 2015; Kjær 2014). Among Sisters Hope inspirators are the international performance artist Marina Abramović, who is known for performances that involve risk, endurance, and bodily injury (FischerLichte 2008, 11, 14), as well as the Danish-Austrian group SIGNA, who invited 
Danish citizens to a controversial sadomasochistic Vila Salò in 2010 (SkjoldagerNielsen 2011). While Sisters Hope performances may be softer than those of Abramović and SIGNA, Gry generally encourages expressivity and strangeness, reminding performers not to compromise intensity in polite consideration for participants. When a new performer suggested to offer water to participants who waited for hours to enter a performance in 2017, Gry intuitively responded that we are no convenient hotel, and that temporary suffering is part of the experience. In addition to this hotel analogy, the director of a renowned Danish performance laboratory called Hotel Pro Forma has radically associated performance with terrorism, in the sense that it makes us question reality and frames of reference (Dehlholm 1993, 92).

During my own involvement since 2015, a key focus of Sisters Hope has been to oppose 'the outside world' and 'everyday life'. These emic expressions figure as common-sense concepts that refer to non-sensuous mainstream living in our (Northern European) part of the world. The focus is practiced, for example, through de-branding [e.g. using tape to cover brands on tooth paste], going analogue [avoiding or hiding electronic devices], and replacing small-talk, high pace, and loud surroundings with slowness and silence. The intention is to create an immersive 'otherworldly' space; a coherent 'in-its-own-world' that absorbs participants (Machon 2013, 21, 93-95; Ejrnæs 2018b, 6). This otherworld is thought of as a space-in-between that temporarily puts everyday life on hold and has a liminal transformative potential (Ejrnæs 2018b, 6). In Sisters Hope, transformative impact is thought of in positive terms and as a general criterion of success that justifies artistic practice. The Sisters Hope project is inspired by van Gennep and Turner (Krøgholt, Hallberg, and Lawaetz 2013, 98), and we design pre- and postliminal rituals that frame participants journeys (Ejrnæs 2018b, 12). Sisters Hope further reflect what performance scholar Jon McKenzie ([2004] 2016) has described as a 'the liminal-norm' to equate liminality with transformative efficacy in performance art, despite the fact that Turner himself thought of liminal rites as reproductive rather than transformative (Turner 1974, 84-86).

In this article, I aim to shed light on the interconnection between extremity and transformative impact in Sisters Hope performance art, through the analytical lens of examples. Anthropologists have traditionally used examples as particularities - illustrations or exemplars - that refer to general theories or universal patterns. More recent studies have foregrounded the power of examples in themselves and in their horizontal relation to other examples (Højer and Bandak 2015). Inspired by this direction, I explore how Sisters Hope practitioners continuously manifest The Sensuous Society through examples of and for a sensory-poetic future. I argue that framing is key to whether Sisters Hope examples appear extreme and 'work' as transformative counterparts to 'the outside world'. Extremity in performance art examples, as I conceive it, is a matter of contrasting and blurring boundaries between imagination and reality; a matter of evoking liminality and thus both crisis and potentiality. Building on van Gennep's theory on rites of passage (1960), Victor Turner understands 'liminality' as a transitional phase caused 
by a temporary suspension of social norms (Turner 1970, 94-95). In this ambiguous betwixt-and-between, it is the subjunctive mode of what if that prevails; what may be, might be, could be, or should be (Turner 1980, 157). I suggest that extraordinary imaginative possibilities become future horizons in the present (Crapanzano 2004, 64-65) when we engage our embodied minds in extreme examples over time. I conclude the article with a discussion on whether the critical position of performance art at the margin of society limits or enables radical transformation, and on the potential link between marginalization and societal fear of the unknown.

\section{Manifesting Sisters Hope}

The Mechanic is typewriting a portrait of The Sister. It is morning in the academy, and I sit as an observer by the wall. I feel invisible in the dim light from the chandeliers, and from this point of view, all shapes appear in harmonic symmetry. I know this act of typewriter-portrayal, and I cherish it as a part of Sisters Academy. In respectful distance, other staff members linger in the periphery, and I sense a condensed atmosphere of patient breathing as the typewriter cuts through the silence in a steady pace. Then loud screaming enters the soundscape, and I expect it to be The Wild's screaming class. For confirmation, I rise to my feet and follow the sound till I reach The Wild's tableaux. I hear her yelling in a sore voice: 'Why are you holding back!? You have more power than this! Come on! Use this, out with it!' I smile before returning to the portrait area behind the curtain 15 meters away. I detect no disturbance, and no one seems to be bothered by the screaming close by.

The situational description depicts a morning in Sisters Academy by the end of a large-scale manifestation in 2017, when I did my master's fieldwork. Besides my anthropological research, I engaged as a full-time performer as part of 'The Staff'. I engaged as my Poetic Self called Flow along other poetic selves such as The Mechanic, The Sister, and The Wild. I will return to the emic concept of poetic selves, but for now, the vignette serves as a peek into the otherworld of Sisters Hope.

Over the past ten years, Sisters Hope have 'manifested' through temporary 'manifestations' that have lasted in between minutes and months. Sisters Hope is mostly known for a project called Sisters Academy; a temporary school world that unfolds in various locations through large-scale productions. One large-scale format is The Takeover, developed in collaboration with school institutions. For two weeks, Sisters Hope performers engage in sensory and poetic explorations with teachers and students inside a school that has been aesthetically transformed through light, sound, and set design [scenography in performance art]. The other large-scale Sisters Academy format is called The Boarding School, and this format has been realized twice in collaboration with art institutions. Whereas Takeover-projects depend on pragmatic maneuvering in educational system, The Boarding School 
allows for more extensive frameworks. ${ }^{1}$ For a temporary period of one month, adults over the age of 18 can sign up to become a Student for a minimum of 24hours. Recently, Sisters Hope has initiated a new project called The Sensuous City, which took place in Copenhagen through a collaboration with Metropolis - KIT (Copenhagen International Theatre) in 2019, and this is planned again for 2021. In this project, everyone can sign up to become a Sensuous Citizen for 24 hours. Apart from large-scale productions, Sisters Hope engage in small interventions, and Gry gives speeches and workshops in different contexts. ${ }^{2}$

Inspired by performance studies, we may think of Sisters Hope performance manifestations as events instead of autonomous art works, thereby focusing on processual and emergent phenomena, along with the bodily co-presence of performers and spectators (Fischer-Lichte 2008, 162, 165). 'Interactivity' is a central performance art strategy in Sisters Hope which refers to how 'co-participation in a joint ritual' replaces traditional actor-audience divides (Hallberg 2017, 45). In anthropology, the event has shown to be a useful unit of analysis, and according to performance anthropologist Dwight Conquergood, we can access dynamic cultural processes through culturally (meta-)reflexive events such as rituals, ceremonies, or contests (Conquergood 2013, 18-19). But how do Sisters Hope manifestations relate to one another, to the visionary outset, and to the society in which they unfold?

To shed light on these questions, I find analytical interest in the idea of lateral examples that inspire, evoke, and set into motion (Højer and Bandak 2015, 7). Let me first draw a comparison to the anthropologist Stine Krøijer's (2015) perspective on exemplification among left-wing radical activists in Northern Europe. Krøijer finds that activist acts such as demonstrations or dumpster diving figure as examples of and for the future (Krøijer 2015, 79). In Krøijer's understanding, these activists do not follow ideological programs or determinate end-goals, but rather exemplary 'good style' (Krøijer 2015, 87). The affinity between Krøijer's interlocutors and Sisters Hope is not only regional, but also thematic in the sense of explicit activist intentions. Activism is a so-called 'logic' in Sisters Hope, along with pedagogy, research, and performance art (Hallberg 2017, 43). These four logics are part of a theoretical and methodological framework which also includes The Sensuous Society manifesto. Having this framework in mind, I will not reduce Sisters Hope to a practice of examples, but it might be even more misleading to think of it as pre-formed theory put into practice. Sisters Hope performers have varying understandings of the project, and I have often heard experienced performers tell newcomers to be patient, as understanding evolves through practice over time. In line with this thinking, I previously suggested the perspective of a situated learning process (Lave and Wenger 1993) where experienced performers are positioned as gatekeepers to tacit knowledge and insider secrets (Ejrnæs 2018b, 58).

\footnotetext{
1 See film and photos from The Boarding School in 2015 and The Takeover in 2016 for comparison (Sisters Academy Sweden 2020).

2 Find past and future projects on the website (Sisters Academy Projects 2020).
} 


\section{Maja Ejrnas - What if Imagination Were Real?}

In my understanding, Sisters Hope develop through exemplary events that model future practice. Sisters Hope exemplars are not articulated as 'good style' but as something that 'works'. Similar to Krøijer's interlocutors, Sisters Hope do not evaluate practice in relation to specific end-goals, but rather in relation to Sisters Hope aesthetics, judged transformative impact, and in opposition to ordinary living. There is no template of The Sensuous Society, but rather a visionary framework and performers' intentions to evoke sensory awareness. We can here think of evocation as a nonrepresentational motion that gives way to emergent phenomena (Tyler 1986, 129, 133). The act of evoking is at the center of performers' attention, and we set things in motion without knowing, nor taking full responsibility for, the outcome.

In emic theory, 'simplicity works', and Gry has recently put more emphasis on how we refine practice through repetition. In my understanding, repetition often makes 'working' Sisters Hope exemplars, rather through reiterative group processes than subjective choice making. Exemplary practice may occur by coincidence as in the case of chanting on chairs; a performer suggested that we could all chant while standing on chairs before dinner, and now, five years later, this has become a living tradition. Similarly, parts of the set-design are furniture and objects that were found coincidentally in second-hand shops, and through continuous instalment and replication, they have become characteristic of Sisters Academy.
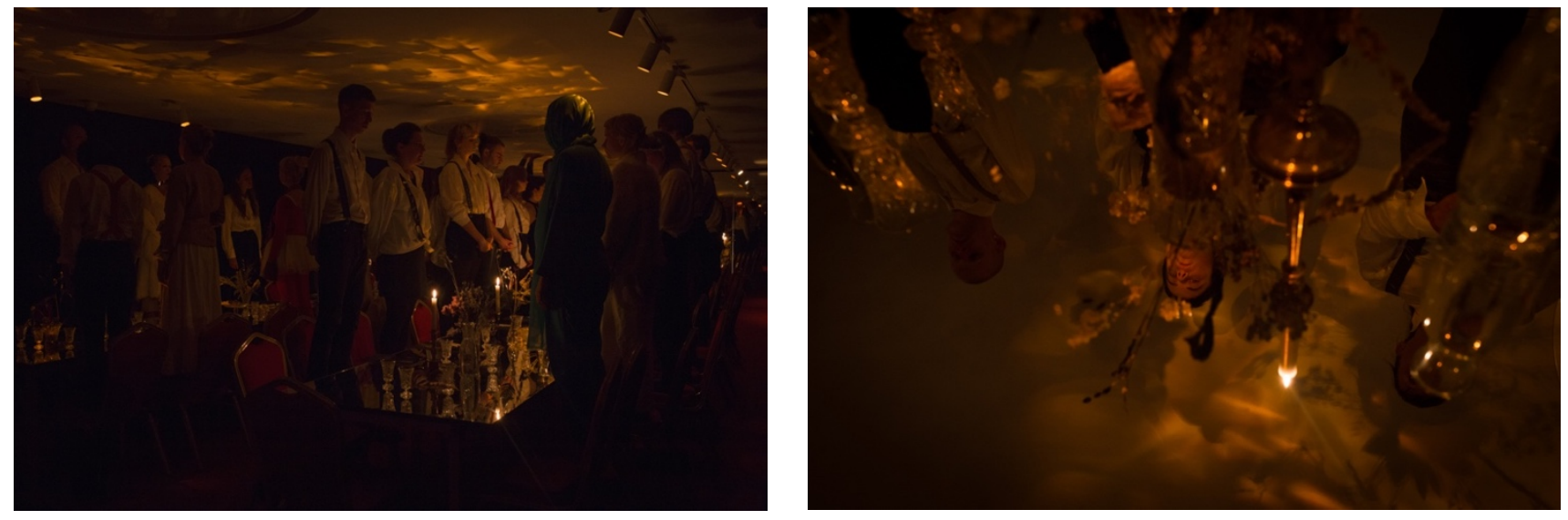

Fig. 1 Chanting on chairs in The Dining Hall. Sisters Academy - The Boarding School by Sisters Hope. Photos: I diana lindhardt.

Following on from this, we may think of the totality of exemplars as a social aesthetic landscape; what film ethnographer David MacDougall understands as the interrelated characteristic objects, actions, and ideas in a given field (MacDougall 1999, 5). In Sisters Academy, such landscape of exemplars would include red carpet, soundscape, the porcelain cat, the guideline to speak English, blindfolds, cat 
suits, slowness, and silent dinners (Ejrnæs 2018b, 29). The idea of a social aesthetic landscape may sharpen our awareness of how exemplars interrelate at the same level and allow us to transcend general-particular or theory-practice correlates. While some Sisters Hope examples are explorations of and for what The Sensuous Society could be, others figure as exemplars for future evocation of sensory transformation. To better understand how we manifest and develop Sisters Hope, we can thus think through performative examples that work as stylized self-referential reenactment, where change is a matter of slight deviations over time (cf. Butler 1993, 225-27; Derrida 2007 [1972]; Fischer-Lichte 2008, 27-28; Sjørslev 2012, 221).

\section{Framed Evocation}

Framing is key in a performance art context where explorative examples and exemplary practice unfold and replicate through different settings. However, I find framing to be a challenging analytical concept as it is used (slightly differently) on emic and etic levels and has wide-ranging applications. In the following analysis, I draw on Gregory Bateson's seminal thinking on framed sociality that has inspired performance-oriented anthropology (Sjørslev 2007, 1-2, 18-19). Bateson (1972) proposed the idea of meta-communication to account for how social beings navigate between play and seriousness. According to Bateson, we separate play from seriousness through exchange of 'meta-communicative messages' that signal: this is play and thus not seriousness (Bateson 1972, 178). Bateson's theory is also reflected in Erving Goffman's thinking on how people refer to meta-communicative keys such as make-belief, contest or ceremony when they respond to the question of 'what is it that is going on here?' (Goffman 1974, 44-48, 58). From this theoretical outset, we can take a look at The Evoker as a Sisters Hope exemplar that unfolds in different physical and meta-communicative frames. 'The Evoker' is a socalled Function that Sisters Hope performers can 'step into' during manifestations. The Evoker wears black skirts, white shirts, and sometimes a white tulle wrapped around the head, its primal function being to evoke sensuous and poetic modes of being.

Inside the frame of The Boarding School, Evokers conduct rituals that mark the initiation and closure of The Students' 'journeys'. They 'uphold the space' through maintenance duties, such as changing bed sheets, and they blend in with the surroundings. In the social aesthetic landscape of The Boarding School, The Evoker appears rather ordinary among distinctive performers with expressive behavior, and the intention to evoke sensory modes of being is supported by metacommunicative messages; participants agree on being in a temporary sensory academy. Though some participants are confused about blurry boundaries between play and seriousness, the frame of an art institution creates certain expectations and acceptance of what is going on here (Fischer-Lichte 2008, 201).

We can compare this framed Evoker example with The Evoker in another format called Sensuous Governing, which took place at Copenhagen City Hall during the 


\section{Maja Ejrnes - What if Imagination Were Real?}

spring of 2019. In this project, performance manifestations lasted for a couple of hours, during which Sisters Hope performers would 'step into' The Evoker function and facilitate participants on sensory journeys. Part-time blindfolded and in a soundscape of Evokers humming a simple melody line, participants were guided from one soft Evoker hand to another until they arrived at the basement, where The Sister facilitated a process around The Poetic Self and visions for a future city. ${ }^{3}$ Similar to The Boarding School, The Evoker fit in the visual aesthetics of the City Hall, but the metacommunicative frame was more ambiguous. While all guided participants had signed up to partake in the performance, The Evokers were not expected by employees at the City Hall. Our gatekeeper was a woman with over 40 years of work experience at the place and interest in Sisters Hope. Neither guards nor politicians or other visitors had been informed of our unofficial access, and unlike in The Boarding School format, The Evoker thus intervened with a group of observing participants, who involuntarily became part of the performance.

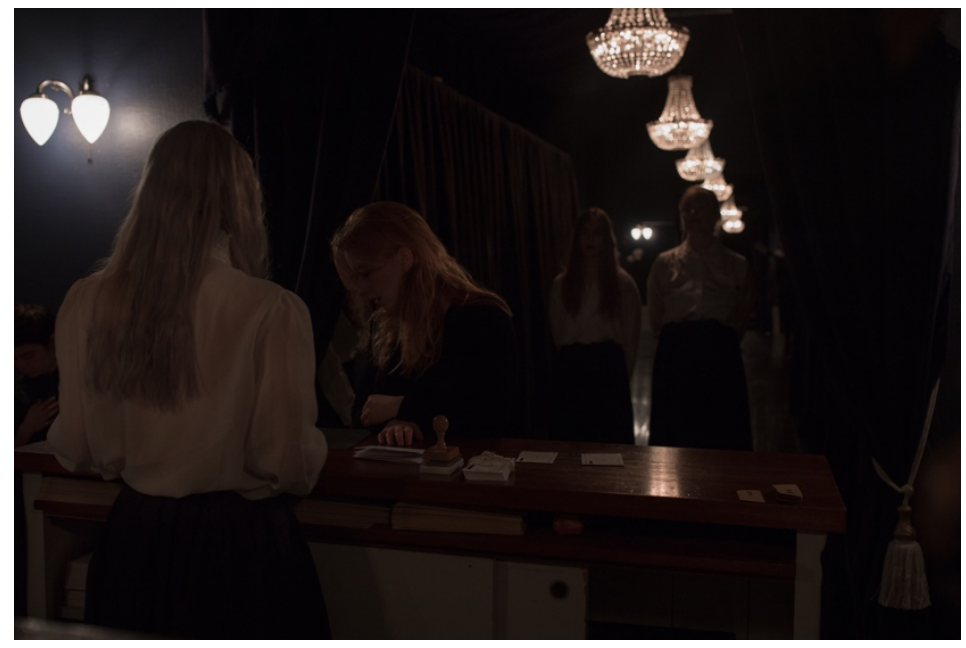

Fig. 2 The Evoker stamping a Student's identity card. Sisters Academy - The Boarding School by Sisters Hope. Photo: I diana lindhardt.

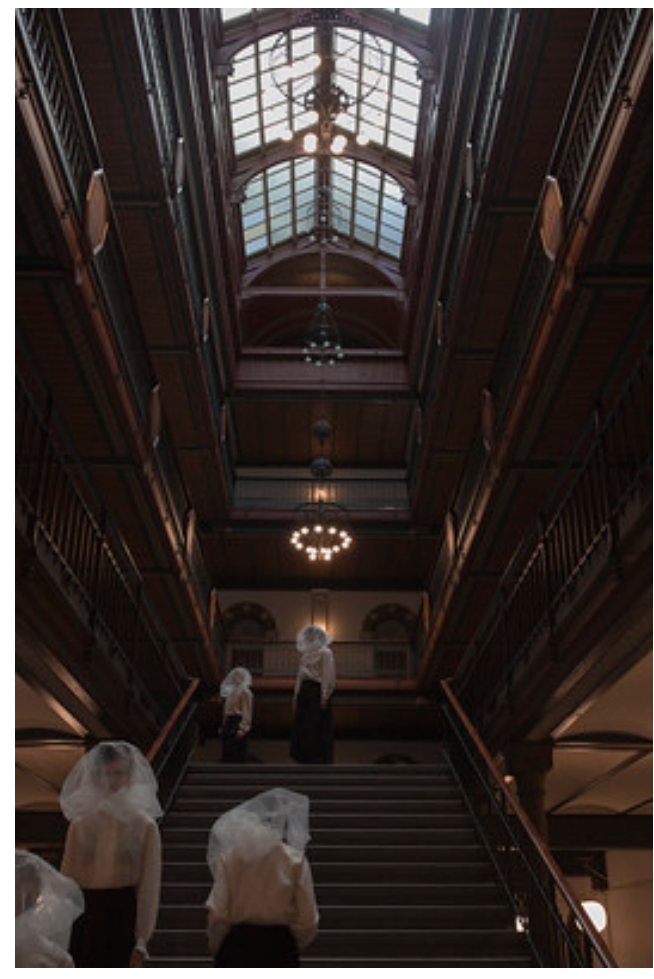

Fig. 3 Evokers in Sensuous Governing - The City Hall of Copenhagen by Sisters Hope. Photo: I diana lindhardt.

${ }^{3}$ See film documentation for an audio-visual impression of the performance (Sisters Hope 2019): https://vimeo.com/344743308 
Maja Ejrnes - What if Imagination Were Real?

\section{Mattering Place}

Parallel to immersion and interactivity, 'intervention' is an explicit performance art strategy in Sisters Hope - that is to intentionally intervene into and impact everyday life worlds (Hallberg 2017, 45). Sister Hope performers are used to navigate within ambiguous frames outside of art institutions, and during our initial rehearsals at the City Hall, some performers tried to engage in subtle poetic encounters with employees; through acts such as eye gazing or giving notes with small ink-written messages saying: 'the city as soft as a body'. In response, the guards firmly asked us not to interfere with them, as this prevented them from attending to their duties. Some weeks after the manifestation, our gatekeeper further told us that several politicians had been frightened by us.

To advance our understanding of this framed evoker example, we can turn to Mary Douglas' concept of 'matter out of place' as disorder within an ordered context (Douglas [1966] 1996, 37). According to Douglas, matter out of place is potentially dangerous, as it threatens cultural coherency, and she finds that people cope with it through strategies such as re-classification, avoidance or physical control (Douglas 1996, 39-40). While some visitors and politicians avoided eye contact and passed by us in a great hurry, others sought classificatory clarification through curious questions or skeptical comments about whether we were actors, nuns, or beekeepers. I recall guards passing by with loud footsteps and small talk at times when we were gathered and quietly humming in the basement. Were these acts signs of thoughtlessness or a display of physical control to re-establish hierarchical order caused by uneasiness with our presence? I did not inquire into this micropolitical tension by talking to any of the guards, but instead maintained a low profile and respectful distance, not risking our unofficial access or to be reclassified as illegal matter out of place.

It was our intention to explore the idea of governing a city through inhabiting and guiding sensory walks in the City Hall. While the manifestation was more hidden from public attention than other activist performance events, it can still be seen as a meta-social commentary in an established place of power (Sjørslev 2012, 218). By standing at the back entrance and welcoming guests through soft and slow gestures, The Evoker entered the guards' official domain and ventured into a nonverbal negotiation of the place. Even if there is no articulated feminist agenda at the core of Sisters Hope (cf. Ejrnæs 2018b, 34-35; Senderovitz 2018, 13), the intended collective Evoker manifestation may be thought of as body politics in a masculine hegemonic arena (cf. Kelada 2015; Nail 2012; Butler 1993). In addition to a structural-symbolic analysis, we can thus turn to Judith Butler's performative take on matter as a process of materialization that stabilizes boundaries, fixity, and surface over time. Rather than static matter out of place, could our bodily copresence be cast as mattering place through reiteration, refiguring future horizons through disruption? Or did we simply reinforce dominating power structures through feminine Evoker gestures? (Butler 1993, 9, 53). 
In response to a guided journey within the municipality, a Danish journalist concludes that 'the aesthetic Sisters Hope intervention into the corridors of power went surprisingly smooth; business continued as usual and no raised eyebrows followed the ritual activities' (Dithmer 2019, my translation). In the light of the journalist's short, blindfolded visit, this utterance appears slightly ignorant or ironic, but it touches on key questions regarding the conditions that enable and limit subversive performance art. In order to be tolerated inside the City Hall, we had to keep a certain distance and adjust our practice to the work life in place. The riskiest part of the performance was probably a so-called 'stone ritual', which I designed during a school Takeover in 2016 and facilitated in the basement during Sensuous Governing. With help from co-performers, I invited blindfolded participants into a chanting recitation of 'thank you' in a masked phonemic version while knocking two cobblestones against each other in pulsating motion. I found this to be a powerful performative ritual where citational iterations formed an uneven soundscape of voices and stones: clashing, merging, and gradually increasing in volume and intensity. Were we then forming an alternative language at the foundation of a place with significant matter, mattering that same place through reconstructing building blocks and bodies? In relation to this question, it is worth mentioning that we were asked to be more discreet after the first performance, as the stone sounds were found too loud and disturbing. And even though the stone ritual figures as an example with transformative potential, we should not confuse a bounded performance act with performativity as the ongoing reiteration of (partly opaque) norms (Butler 1993, 234). In other words, mattering matter needs time and continuous repetitions.

\section{Institutionalized Art and Sensory Living}

The comparison between The Boarding School and Sensuous Governing illustrates how meta-communicative framing influences the responses that The Evoker, as a replicated Sisters Hope example, evokes. It is tempting to conclude that the frame of an art institution gives meta-communicative clarity about what is going on, but this is not always the case. As part of Sensuous Governing, Sisters Hope took part in the international museum conference called CTM (Communicating the Museum). On June 18, 2019, we were to present at the Danish art gallery called Louisiana. When we were not (officially) performing, we were free to wander off and visit museum exhibitions. Still being in The Evoker mode and clothing, some museum visitors impulsively drew back by the sight of us, others were intrigued, a few followed us, and some did not seem to care much. I clearly remember a moment when another Evoker and I met a group of public-school students in a passage.

The group is filled with noise and the students appear distracted while their teacher tries to explain them something. We slowly approach in silence, and suddenly they stop speaking, instantly shifting their attention to us. One student asks 'Hvem er de?' [Who are they?], while another student whispers 'Wow, det 


\section{Maja Ejrnes - What if Imagination Were Real?}

er uhyggeligt' [Wow, this is scary]. As we pass the group, I briefly stop and place a hand on the shoulder of one of the students, who freezes by the touch.

The description depicts a situation when The Evoker scared a group of school students. The students did not expect to meet us, and the teachers could not provide any explanatory information on who we were or how one was supposed to interact with us. Within the frame of the Louisiana art museum, we were not inappropriate matter out of place but rather living art with a mysterious appearance that challenged regular boundaries between art and audience. The apparent shock effect, silence, and comment that 'Wow, this is scary' invite the Freudian idea of the uncanny [unheimlich] as the sense of disquieting strangeness that arrives when (secretly familiar) animistic thought appears in material reality (Freud [1919] 2003; Good 2019, 418; Seulin and Bronstein 2019, 3). In relation to aesthetic art experience, psychologist Gregorio Kohon (2019) elaborates on 'the uncanny' as an encounter with the unconscious negative; a transitory glimpse of a dream-like reality, which may cause both horror and wonder. With the concept of the uncanny in mind, I suggest that our Evoker bodies (temporarily) distorted reality by manifesting animistic (e.g. ghost-like) images in the student encounter. I personally recognize the Chinese artist Ai Weiwei's experience of being 'turned on' by uncanny 'unfamiliar reality' that creates a 'sense of aesthetic excitement' (Kohon 2019, 84). In Louisiana, The Evoker certainly caught the students' attention, and I can only hope that we enlarged their sensory imagination of possible realities, rather than leaving them with a traumatic experience for life.
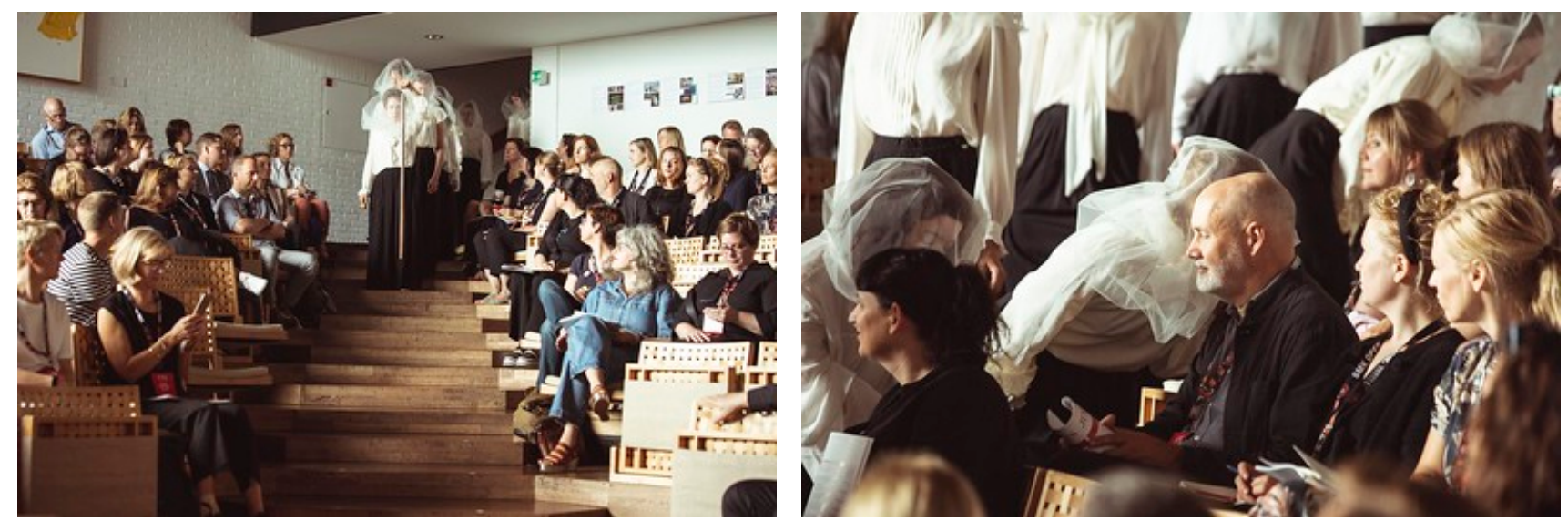

Fig. 4 Evokers in 'artistic interventions' at CTM in Louisiana. Photos: Lars Krogsgaard

During our official performances at CTM, The Evoker was surrounded by less ambiguity. These so-called 'artistic interventions' were part of a tight program of speakers from art institutions and academic backgrounds that took place in a conference room at Louisiana. The first intervention was part of the program headline INCITE YOUR AUDIENCE and was a 10 minutes' walk in a slow pace while whispering poetic phrases in the ears of conference participants. The second 
intervention had the headline NEW TECHNOLOGIES, and this time, we walked in a slow pace while a characteristic Sisters soundscape played through the speakers. ${ }^{4}$ Even though the performances only lasted for ten minutes each, several conference participants expressed thankfulness and surprise afterwards. They reportedly found that our presence had been an appreciated invitation to slow down and listen. This feedback is slightly ironic in a conference frame, where the audience is supposed to listen to presentations, but having been to conferences, one recognizes the tiredness that arises after hours of monotonous talking. As a reflective counterimage of busy networking, small talk, and mobile phone distractions, The Evoker succeeded in the intended evocation of sensory awareness. The performance became an invitation for radically different being and socializing that inspired shifts in attention and behavior.

\section{Provoked Body Encounter}

On May 2 (2020), the police stopped The Sister several times when she was covered in red veil during a 30 kilometer walk in Copenhagen (Kjær 2020). The walk was part of a Facebook-transmitted durational performance by the international theatre KIT (Metropolis), in which different artists explored the city in times of coronavirus. Gry later recounted her experience with the police as brutal, uncomfortable, and scary.

In her retelling of the event, she was stopped by a police car at Islands Brygge in Copenhagen around seven o'clock in the morning. The hold-up triggered immediate anger in her; anger of being stopped in the midst of a legal performance, and anger of how strangers are generally met with hostility and accusations. Staying in an English-speaking Sisters Hope performance mode, she defended her rights, and this made the police officers more upset. They got out of the car and asked to see her ID, which she did not bring on the walk. She hastily started to look for a formal paper from Metropolis, which she had brought by coincidence. When she discovered that she had dropped it on the ground and ran to fetch it, it might have been interpreted as an attempt to escape, and, in the spur of a second, she was taken to the ground and handcuffed. In retrospect, Gry emphasized how the extreme situation was unintended, and that civil disobedience is far from Sisters Hope activist strategies. She also mentioned that she did not encounter police problems in any of her previous public space performances, when she was equally covered in red veil. Her hypothesis was therefore that the corona situation had triggered a heightened level of fear towards the unknown and a temporary police state controlling all public behavior. When lying face down and screaming to the ground, The Sisters (in Gry's memory) had a flashing Handmaid's Tale moment, doubting whether Sisters Hope's radical performance practice would be impossible henceforward.

\footnotetext{
${ }^{4}$ The soundscape has developed through three versions since 2014 , and you can listen to each of them on the website of Sisters Academy (Sisters Academy Sounds 2020).
} 
From an etic perspective, we can place this apparently extreme Sisters Hope example in a meta-communicative coronavirus frame where people are more suspicious and on their guard in public space. The Sister was not stopped because she offended COVID-19 restrictions but because of covering herself in red veil. She thereby manifested an image associated with a Muslim woman in burka; a relative extreme example in Denmark, which is (legally) judged to be (national) matter out of place and controlled through prohibition. A bit ironically then, Gry was not fined for covering up her face but for creating 'disorder in public space', as she recounted. When she was stopped a second time on her walk by different police officers, she immediately removed her veil to explain the performance art situation. According to Danish law, art namely serves a 'creditable purpose' and is thus excepted from the face-covering ban (Politi 2020) or 'the burka ban' [public discourse].

\section{Extremity in Contrast and Ambiguity}

I have elaborated on The Evoker as a replicated Sisters Hope example that appears differently according to its framing. I have analyzed evocation of intended and unintended reactions among assigned and coincidental participants. In The Boarding School format, Evokers maintain order in Sisters Academy among voluntary participants, whereas we evoked disturbance and disorder among involuntary participants at the City Hall. I have analyzed how Sisters Hope examples figure as welcomed counterparts to ordinary living when participants agree on metacommunicative framing, but as soon as boundaries between art and reality start to blur, evocation becomes a risky matter. Through framed performance art examples, we have seen how the sense of extremity is linked to contrast or ambiguity. While the latter may be frightening and limited through coping strategies, it holds a key to transformation, in the sense of expanding or distorting experienced reality.

From a Sisters Hope activist point of view, it is important to 'democratize the aesthetic dimension' by reaching people who do not seek out performance art by themselves. In the City Hall, it is questionable whether we reached, or simply scared, the employees, but The Evoker did evoke reactions, and from an emic point of view, any transformation is usually preferred in favor of ignorance. Yet the police encounter was unintended and will not replicate as a 'good example' for Sisters Hope practice. Gry gave me her permission to write in details about the situation in this journal article, but she deliberately asked a journalist from Politiken [Danish newspaper] not to include the brutal handcuffing in a media story, as this would attract all public attention. While there seems to be a constant desire for extreme news in the media, this kind of extremity was found inappropriate in Sisters Hope. The story would have become an 'excessive exemplar' that digest all other material and thereby loses its significance (Højer and Bandak 2015, 8) or power to evoke The Sensuous Society. Following on from this, I find it important to address the question of whether Sisters Hope examples (simply) evoke ephemeral awareness and imaginary play, or actually enable transformative impact. 
Maja Ejrnes - What if Imagination Were Real?

\section{Beyond Pretending}

The Poetic Self is a key methodology in Sisters Hope and I find it to be a relevant outset for inquiry into the interplay between imagination, performative action, and experienced realities. The most replicated and characteristic Sisters Hope practice is the 'Poetic Self exercise', which is an imaginative meditation where you lie down with closed eyes for 15-30 minutes and reflect upon your so-called Poetic Self. The exercise is usually guided by The Sister, who starts by clarifying that The Poetic Self is neither a character nor your everyday-life-self, but your 'inner inherent poetic potential'. The Sister then poses 'a series of questions' that you are invited to reflect upon in relation to your Poetic Self, one question being: 'Space. Consider space. What is your body in space? How do you move in space?' By the end of the exercise, you are invited to find a name for your Poetic Self. I have previously argued that the idea of an inherent inner Poetic Self resembles a Western philosophical line of thinking inspired by Christian and Romantic thinkers (Ejrnæs 2018a, 2-3). In Sisters Hope theory, you initially find your Poetic Self through inner reflection and then gradually externalize it into the world through clothing, behavior, and individually designed 'tableaux': spaces for classes and rituals. In my understanding, the practice of finding a Poetic Self includes experimentation and adaption to Sisters Hope social aesthetics (Ejrnæs 2018a). In line with Judith Butler's thinking on performativity as self-construction through corporeal enactments (Butler 1990, 278-79; Loxley 2006, 118), I find that Poetic Selves unfold and expand through repetitive practice; explorative examples that may turn into exemplars of and for inner poetry with time.

Following a general dissociation from theatre in performance art, terminology such as 'stage', 'acting', or 'audience' is avoided in Sisters Hope. Gry/The Sister uses expressions such as 'organic' or 'lived life', and she has frequently reminded performers that 'we are not pretending'. Despite of this intended authenticity, sensations of pretend play or 'fake it till you make it' can occur among performers and other participants. Yet in these cases, participation over time may further individually ascribed authenticity that bears on emotional engagement rather than fixed criteria (Ejrnæs 2018b, 48; Schulze 2017, 43). I personally experienced such change in experience; both during the time frame of an hour and one month in The Boarding School (Ejrnæs 2018b, 45, 62-63).

When Sisters Hope manifest in the format of The Boarding School, some performers live inside of the art institutional building for an entire month. In emic thinking, performers make up the most involved 'participatory level'. Due to ethical considerations, practical circumstances, and my own positioning, I focused on performer participation in my master's thesis, as I explored how articulated longings 'to go deeper' relate to experiences of practice over time (Ejrnæs 2018b). One of my key interlocutors was the new performer Sofia, who went through a visible transformative journey. Sofia, a Danish woman in her mid-twenties, entered Sisters Academy as a confused newcomer and left it as a confident practitioner. I recall meeting her by the restroom at the beginning of the manifestation, when she told me, partly in frustration and partly in despair, how she had to put on a mask 
to survive (Ejrnæs 2018b, 56). In contrast, she was completely unwilling to let go by the end of the month. As she put it in an interview after the manifestation, she got 'pissed off' when asked to 'step out' of her Poetic Self as part of a closing ritual. She explained it as a sense of 'so now we have to stop being ourselves' (Ejrnæs 2018b, 66).

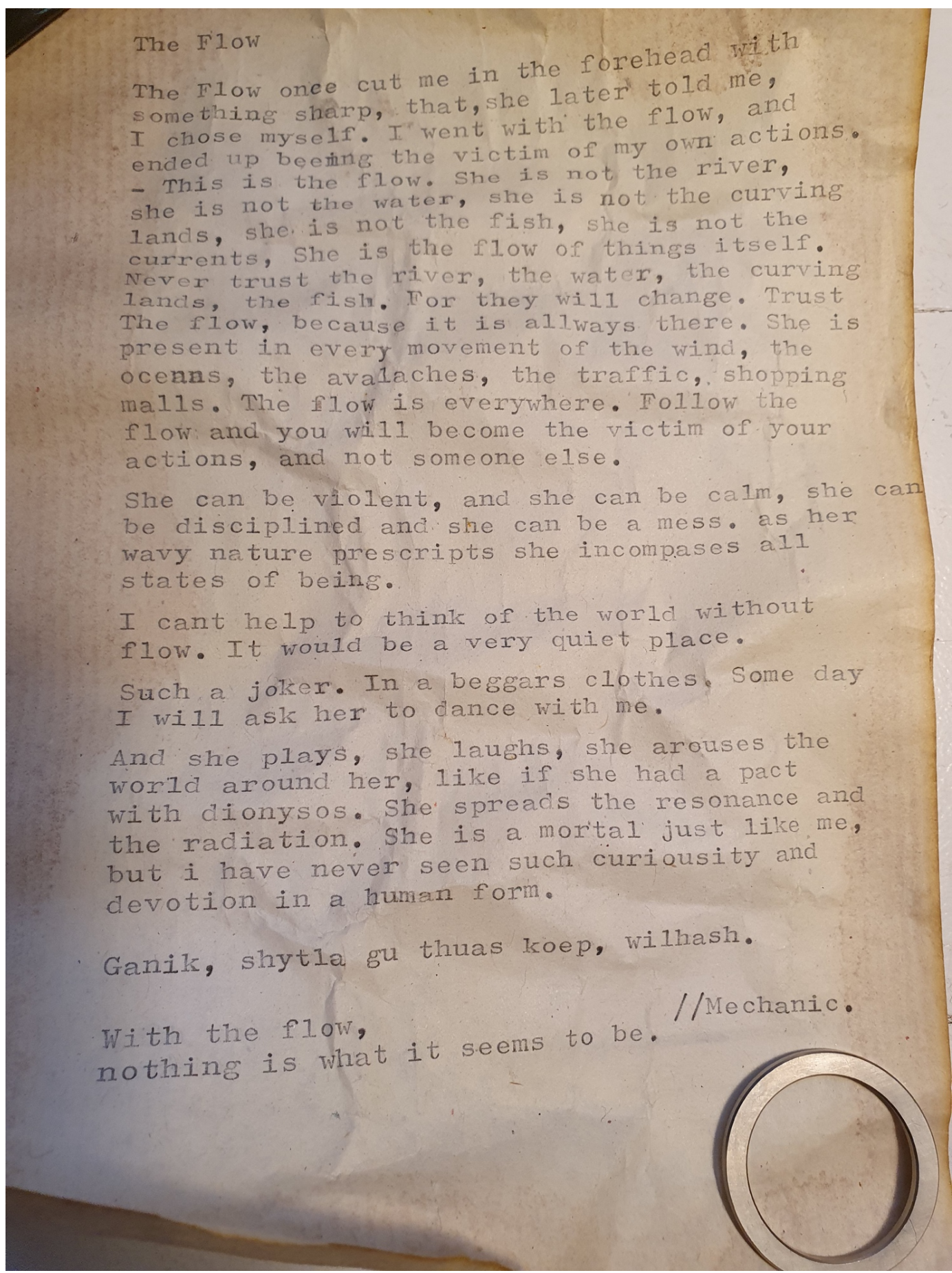

Fig. 5 Typewritten portrait of (The) Flow by The Mechanic. Photo taken by author. 
In Sofia's experience, The Seamstress [her chosen Poetic Self name] was now herself - or a version of herself that she did not want to exchange with any previous self. I myself was also rather immersed by the end of the manifestation, and as I sat reading The Mechanic's typewritten portrait of me - that is, of my poetic self - my cheeks were wet with tears of gratitude. This was not playing reality but real playing.

The transformation from pretend play to experienced authenticity also unfolds as a collective process. In my experience, we were not a group of idiosyncratic individuals by the end of the 2017 manifestation, but rather a synchronized body acting in fine-tuned concert. Other performers described it as being 'an organism' or 'a sense that we all become one' (Ejrnæs 2018b, 64). Such accounts parallel Turner's idea of 'spontaneous community' as moments of mutual understanding, synchronicity, and lack of pretentiousness, which he associates with liminal processes and 'anti-structure', understood as the dissolution of normative social structure (Turner 1974, 60, 79). The anthropologist Camilla Stubbe Teglbjærg draws on this concept in her study of the jazz scene in New York, where musicians talk about magical moments of 'making it happen' when musical interaction forms a synthesis, and all attention is focused at once (Teglbjærg 2007, 150). Sisters Hope examples thereby do not just 'entail the setting in motion of particular trains of imagination' (Højer and Bandak 2015, 7), but further evoke sensory experiences of alternative (intensified) being, as they are lived in the present. In the manifesto, Gry writes that The Sensuous Society is 'no utopia', in the sense of an imagined dream world, but rather a framework to embody future visions through explorations in the present (The Sensuous Society 2020). Sisters Hope examples may thus occasionally (or gradually) transform imagination into lived experience, and thereby evoke a sense of 'radical change unfolding' (Krøijer 2015, 90). Rather than fixed images of a future utopia, Sisters Hope examples work like utopian performatives. Performance scholar Jill Dolan understands 'utopian performatives' as 'the small but profound moments' that 'lift everyone (...) into a hopeful feeling of what the world might be like if every moment' was as 'aesthetically striking' and 'intense' (Dolan [2004] 2016, 240). But what happens to such radical change unfolding when the manifestation ends?

\section{From Imagination to Everyday Living}

The following situational description is written at the time of transitioning out of The Boarding School, and it depicts my experience of the dinner celebration that took place immediately after an intense end ritual.

I move to The Dining Hall which is already filled with the production team and employees from Den Frie. It is overwhelming suddenly to have these people inside of Sisters Academy with their everyday life clothes and Danish small talk. I pause in astonishment by the sight of Royal beer cans among crystal flowers on the shining mirror tables, and I realize that the space is filled with foreign objects that do not belong here: mobile phones, labelled soda bottles, personal belongings, jackets, and bags. As we gather around the dinner tables, I sense a radical change 


\section{Maja Ejrnes - What if Imagination Were Real?}

in atmosphere. This is not a ritualized silent dinner in slow pace, but a hectic dinner full of joking and loud Danish conversations. It is not until I leave the table that I realize how full I am and how I almost forgot to chew the food' (Ejrnes 2018b, 66-67).

Like most Sisters Hope performers, I was overwhelmed by the sudden transition, which appeared rather brutal in the moment. I impulsively reacted to beer cans, small talk, and mobile phones as matter out of place in the social aesthetic landscape of red light and Poetic Selves (Ejrnæs 2018b, 67) - extreme examples of the outside world after one month of everyday living in The Boarding School. In the description below, I try to capture my experience of the rapid transition.

When we have unloaded the last removal van with furniture at the storage place in Slangerup, after three days of effective post-production, we return to Den Frie to realize that the museum building is already populated with new exhibitors. When I walk through the building with Tina, we laugh in astonishment by the surreal sight of a museum reception in the place of what had just been our home a moment ago. In this apparently otherworldly reality of a wide, white, and bright contemporary art center in Copenhagen, I am tempted to question: Was Sisters Academy just a dream?' (Ejrnes 2018b, 68).

In a sense, it was kind of magical how the physical-aesthetic frames of Sisters Academy disappeared within the course of three days. However, invisibility in the outside world does not imply that change did not unfold on the inside, and utopian performatives will reappear and replicate through future Sisters Hope examples and exemplars - practice that involves navigation in a subjunctive 'what if' mode where dream and reality are opposite sides of a coin that can easily flip.

\section{At the Margin of Society}

Sisters Hope is not a parallel society, but rather a community of practice with its own negotiations and social dramas (Ejrnæs 2018b, 30; Wenger 1998, 72-73). Sisters Hope 'work' inside of the outside world and we paradoxically depend on the society we oppose (Ejrnæs 2018b, 11). We rely on project funding and collaboration with hosting institutions, and since 2015, performers have complained about how pre- and post-productions are full of rational planning, meetings, time pressure, and small talk. To use an emic way of speaking, we still 'haven't cracked' how to build and pack-down Sisters Academy outside of 'the old [ordinary] paradigm'.

The outbreak of the COVID-19 pandemic in the spring of 2020 made Sisters Hope's dependence on 'the outside world' particularly visible. While Sisters Hope visions were born out of the financial crisis in 2008, the pandemic instantly triggered alarming reactions to limit risk and damages. After 12 years of Sisters Hope development, there was more at stake now as projects got cancelled and we had to compromise practice through physical distancing or online platforms. There has 
been expressed critique of the political downgrading of an economically 'bleeding' Danish art and cultural life during the coronavirus shut-down (Ritzau 2020; Rix 2020). The critique grew most furious when the Danish cultural minister commented, in a press interview, that she found it inappropriate to talk about art and culture as long as there was a shortage in protective gear at the hospitals (Borup 2020). Apart from the socio-economic precarious situation, the coronavirus has thus displayed a devaluation of art practice in times of crisis, thereby casting doubt on the idea that performance art actually serves a creditable purpose in society.

\section{When Transformation is Possible}

Optionality is a keyword in Turner's conceptualization of liminoid performance events such as theatre plays, sport competitions, and festivals - events that resemble liminal rites of passage, but belong to the category of leisure-time, where participation is a matter of choice rather than obligation (Turner 1974, 64, 72, 74). To avoid Turner's outmoded dichotomy between pre- and post-industrialized societies, we can think of a continuum of extreme sensory limen-events that temporarily contrast the mundane (Spiegel 2011). In the idealized 'liminal pole', events are cyclical society-wide inversions intended to reproduce structures and reinforce solidarity, while events in 'the liminoid pole' are driven by individuals or interest groups that intentionally subvert and disrupt society in ways that are constitutive of transformation (Spiegel 2011, 15-16). In this continuum, Sisters Hope seem closer to the subversive liminoid pole, but the liminal is also reflected in our repetitive practice. As alternative narrative to Gry's emphasis on continuous refinement through repetition, other performers have problematized how repetition limits exploration and renewal. During Sisters Academy in 2017, a co-performer drily uttered that this was nothing but 'a reproduction of The Boarding School in 2015'. Such utterance directs attention to the risk that we not only enable, but also prevent, transformation by (safe) repetition of exemplars that (are found to) work.

Returning to the idea of optionality, most participants voluntarily choose to take part in Sisters Hope performances, and we thereby only reach a fraction of society. A key exception to this optional premise is when we inhabit school institutions during Takeover formats. For an intense period of two weeks, all students and teachers are obliged to participate in Sisters Academy, and this mandatory premise usually spurs (both positive and negative) extreme reactions. As an illustrative example, a group of critical parents reportedly formed a Facebook hatred group towards Sisters Academy in 2016, during our Takeover at a college high school for students aged 15 to 18 in Simrishamn (Sweden). A parent from the fire department further arranged a security check in what appeared to be an attempt to deem the project illegal. Such responses are generally explained as 'fear of the unknown' in Sisters Hope, and in line with my previous argumentation, we could think of them as coping strategies to limit matter out of place that threatens cultural world views. In the case of Sensuous Governing, we never had official permission to perform, and critical reactions a year ago now impact negotiations on whether we can return in the summer of 2021. 
But what if we imagine that Sisters Hope governed Copenhagen? Would our performance examples turn into reproductive liminal rites and loopholes for rebellion or would they materialize The Sensuous Society? Is the critical marginal position actually the best outset for performance art? And did we already, actually performatively, govern the city? These are all open questions with a certain amount of ambiguity. For the time being, Sisters Hope will continue to evoke extremity through lived examples at the margin of society; an exemplary practice that may turn even more extreme in the future, as we have been invited to take over a Russian school in the summer of 2021 (Rahbek 2020).

\section{Half-open Windows and Portable Doors}

My intention with this article was to explore the idea of extreme examples in the performance art context of Sisters Hope, where visions unfold through temporary manifestations that are usually portrayed as either radical, intense or extreme. From my experienced practitioner position, I elaborated on how Sisters Hope practice develops through explorative examples of what a future Sensuous Society might be like, as well as through replication of exemplars that work particularly well; being aesthetically appropriate counterparts to the outside world that evoke experienced transformation. I zoomed in on The Evoker as a replicated Sisters Hope example through a comparative analysis of how meta-communicative framing influences appearance and impact. I drew attention to how relative extremity is constructive for performance art examples to work, but the brutal police encounter showed how extremity can also distort the example in unwanted directions. Following the question of when and how performance art examples enable transformation, I shed light on the interrelationship between imagination and performativity in the field. Through a focus on long-term performer engagement, I elaborated on transformative processes from pretend play to experienced authenticity. I argued that performance art examples for future 'what if' scenarios come alive when we stay engaged with them in the present, and that lived examples may be so convincing that they make the world outside appear surreal.

I have argued that performance artists intentionally evoke 'what if' modes through extreme examples. One figurative analogy of the extreme 'what if' example could be a half-open window to another potential world. From a distance, the window gives access to an imaginary world, but you can make its small opening wider by approaching it, and eventually, the window might transport you into the other world - if you dare to leave home. Maybe you recognize the sense of simultaneous excitement and fear by the thought of jumping from a window. But what if the jump makes you fly? Then the window would be a 'portable door to magic', to cite a co-performer from Sisters Hope (Ejrnæs 2018b, 72). However, (Western) rational thinking tells us that jumping would make us fall and consequently die, wherefore we better close the window to stay safe.

In Imaginative Horizons, Crapanzano foregrounds the danger, enchantment, and (imaginary) possibility involved in crossing a threshold (Crapanzano 2004: 60-61, 
64-65). As a safe thought experiment, we can think of a scenario in which the guards in The City Hall had accepted an Evoker invitation by returning an eye gaze, a touch, a note with a secret message. What would have happened then? What instantly comes to my mind is the present \#metoo debates on sexism; a meta-communicative discursive frame that would probably influence or prevent such a scenario; the guards [mostly men] not risking being labelled with sexist power exploitation. But what makes up exploitation or manipulation in this context? I will leave this train of thought for future investigation into the blurry field of performance art.

In this article, I have foregrounded extremity as matter with radical potential to shake, distort or invert our sense of reality. I have shed light on the importance of framing, but transformative impact may further depend on participants' openness to experience, withstand, and tolerate strangeness (Kohon 2019, 86-87). In any case, performance art examples can direct attention towards extreme possibilities of life that may ignite hope and ever-further horizons (Agamben 1996, 51; Crapanzano 2004, 104; Kelada 2015, 232). When I talked to Gry on the phone a couple of months after The Sister's Handmaid's Tale moment of despair, she was very hopeful. She told me that she sensed an increased awakening in society.

Something is happening...

\section{Author Bio}

Maja Ejrnæs is a researching performance artist and a graduate anthropologist (cand.scient.anth.) from The University of Copenhagen. Ejrnæs did her master's fieldwork in a large-scale Sisters Hope performance in Copenhagen, and her thesis contributes with insights on practice-based research (PBR) and sensory ethnography, along with knowledge on the intersection between performance art, performance studies, and anthropology. Besides her engagement in performance art practice, Ejrnæs works with Contact Improvisation and Forum Theatre.

\section{Acknowledgements}

I would like to thank my former supervisor Inger Sjørslev for encouragement and insights on genre-specific framing. I am grateful for the feedback from anonymous reviewers, and I thank Oliver Maxwell, Giles Golding, Maria Mouk, and Emilie Koefoed for comments and language editing. Last but not least, I thank Gry Worre Hallberg for devoting her body to Sisters Hope, and for inviting me into the group as a researching performance artist.

\section{References}

Agamben, Giorgio. 1996. "Form-of-Life." In Radical Thought in Italy a Potential Politics, edited by Paolo Virno and Michael Hardt. Minneapolis: University of Minnesota Press. 
Maja Ejrnes - What if Imagination Were Real?

Bateson, Gregory. 1972. Steps to an Ecology of Mind. New York: Ballantine Books.

Borup, Birgitte. 2020. Joy Mogensen: 'Jeg ville opfatte det som upassende, hvis jeg stod og talte om kultur lige nu." Berlingske, March 25. https:// www.berlingske.dk/aok/joy-mogensen-jeg-ville-opfatte-det-som-upassende-hvis-jeg-stod-og-talte-om

Butler, Judith. 1990. "Performative Acts and Gender Construction: An Essay in Phenomenological and Feminist Theory." In Performing Feminisms: Feminist Critical Theory and Theatre, edited by Sue-Ellen Case. Baltimore: Johns Hopkins University Press.

Butler, Judith. 1993. Bodies That Matter: On the Discursive Limits of "Sex". New York: Routledge.

Carlson, Marvin. (1996) 2004. Performance: A Critical Introduction. New York \& Abingdon: Routledge. https://doi.org/10.4324/9781315016153

Chukri, Rakel. 2015. "Febrig drömvärld på Inkonst." Sydsvenskan, September 2. https://www.sydsvenskan.se/2015-09-02/febrig-dromvarld-pa-inkonst

Conquergood, Dwight. 2013. Cultural Struggles: Performance, Ethnography, Praxis, edited by E. Patrick Johnson. Michigan: University of Michigan Press. https://doi.org/10.3998/mpub.4845471

Crapanzano, Vincent. 2004. Imaginative Horizons: An Essay in Literary-Philosophical Anthropology. Chicago: University of Chicago Press. https:// doi.org/10.7208/chicago/9780226118758.001.0001

Dehlholm, Kirsten. 1993. "Performance: En Ombejlet Estetik." In Ritual \& Performance, edited by Jørgen Ø. Andersen. Aarhus: Aarhus Universitetsforlag.

Derrida, Jacques. (1972) 2006. "Signature Event Context.” In Basic Writings, edited by Barry Stocker. London: Routledge.

Dithmer, Monna. 2019. "Sanserne vækkes på 24 timers performancevandring: Lugten af våde sten, parfume og tis kommer helt tæt på.” Politiken, July 9. https://politiken.dk/kultur/scene/art7283957/Lugten-af-v\%C3\%A5desten-parfume-og-tis-kommer-helt-t $\% \mathrm{C} 3 \% \mathrm{~A} 6 \mathrm{t}-\mathrm{p} \% \mathrm{C} 3 \% \mathrm{~A} 5$

Dolan, Jill. (2004) 2016. "Utopian Performatives." In The Performance Studies Reader, edited by Henry Bial and Sara Brady. London: Routledge.

Douglas, Mary. (1966) 1996. Purity and Danger: An Analysis of Concepts of Pollution and Taboo. London: Routledge. https://doi.org/ $\underline{10.4324 / 9781315015811}$

Ejrnæs, Maja. 2018a. "Figurations of The Poetic Self: Self-understanding in a Copenhagen-based performance art project." Graduate Student Essay, Copenhagen University.

Ejrnæs, Maja. 2018b. "To Go Deeper When It Works: Anthropological inquiry into engagement and search for a sense of deeper living in a Copenhagenbased performance practice." Master's Thesis, Copenhagen University.

Fischer-Lichte, Erika. 2008. The Transformative Power of Performance: A New Aesthetics. Translated by Saskya Iris Jain. New York: Routledge. https:// doi.org/10.4324/9780203894989 
Maja Ejrnes - What if Imagination Were Real?

Freud, Sigmund. (1919) 2003. The Uncanny, edited by David McLintock and Hugh Haughton. London: Penguin.

Gennep, Arnold van. 1960. The Rites of Passage. London: Routledge.

Goffman, Erving. 1974. Frame Analysis: An Essay on the Organization of Experience. Boston: Northeastern University Press.

Good, Byron J. 2019. "Hauntology: Theorizing the Spectral in Psychological Anthropology." Ethos 47 (4): 41 1-426. https://doi.org/10.1111/etho.12260

Hallberg, Gry W. 2016. "Keynote: Sisters Academy. Intervenerende performancepraksis og sanselig uddannelse.” BUKS - Tidsskrift for Børne- \& Ungdomskultur 33 (61): 33-66. https://tidsskrift.dk/buks/article/view/23385

Hallberg, Gry W. 2017. "Sensuous Learning." In Sisters Academy: Education for the Future, edited by Rikke Luna, Matias, Nikolaj F. Rasmussen, Gry W. Hallberg, and Nana Senderovitz. Aarhus: I DO ART Books.

Hallberg, Gry W., and Anna Lawaetz. 2011 . "Sisters Hope.” Peripeti 8 (15): 10412. https://tidsskrift.dk/peripeti/article/view/108214

Højer, Lars, and Andreas Bandak. 2015. "Introduction: the power of example." Journal of the Royal Anthropological Institute 21 (S1): 1-17. https:// doi.org/10.1111/1467-9655.12173

Kelada, Mariz. 2015. "Social Change Between Potentiality and Actuality: Imagination in Cairo's Alternative Cultural Spaces." International Journal of Sociology 45 (3): 223-233. https://doi.org/ $10.1080 / 00207659.2015 .1066181$

Kirshenblatt-Gimblett, Barbara. [2004] 2016. "Performance Studies." In The Performance Studies Reader, edited by Henry Bial and Sara Brady. Abingdon \& New York: Routledge.

Kjær, Birgitte. 2014. "Gymnasie-skole i Odense går med i ekstremt eksperiment." Politiken, February 19. https://politiken.dk/kultur/art5503827/Gymnasie-skole-i-Odense-g\% $\%$ C3\%A5r-med-i-ekstremt-eksperiment

Kjær, Birgitte. 2020. "Stoppet to gange af politiet: Kunstner i rødt gik på jagt efter corona-effekten." Politiken, May 2. https://politiken.dk/kultur/ art 7767502/Kunstner-i-r $\% \mathrm{C} 3 \%$ B8dt-gik-p $\% \mathrm{C} 3 \% \mathrm{~A} 5$-jagt-efter-coronaeffekten

Kohon, Gregorio. 2019. "Aesthetics, the Uncanny and the Psychoanalytic Frame." In On Freud's "The Uncanny," edited by Catalina Bronstein and Christian Seulin. Milton: Taylor \& Francis Group. https://doi.org/ $\underline{10.4324 / 9780429287367}$

Krøgholt, Ida, Gry W. Hallberg, and Anna Lawaetz. 2013. "Sisters Academy: Et Uddannelsessystem Neddyppet i Sanselighed.” Peripeti 20: 94-104.

Krøijer, Stine. 2015. "Revolution Is the Way You Eat: Exemplification among Left Radical Activists in Denmark and in Anthropology." Journal of the Royal Anthropological Institute 21 (S1): 78-95. https://doi.org/ $10.1111 / 1467-9655.12167$

Krøjby, Katrine. 2017. "Jeg tjekkede ind i en parallelverden i 24 timer og lod mig (næsten) hjernevaske.” VICE Magazine, 2017. https://www.vice.com/en/ article/qvjxv5/jeg-tjekkede-ind-i-en-parallelverden-i-24-timer-og-lod-mignaesten-hjernevaske 
Lave, Jean, and Etienne Wenger. 1993. Situated Learning. Legitimate Peripheral Participation. Cambridge: University Press.

Loxley, James. 2006. Performativity. The New Critical Idiom. London: Routledge. https://doi.org/10.4324/9780203391280

MacDougall, David. 1999. "Social Aesthetics and The Doon School." Visual Anthropology Review 15 (1): 3-20. https://doi.org/10.1525/var.1999.15.1.3

Machon, Josephine. 2013. Immersive Theatres: Intimacy and Immediacy in Contemporary Performance. London: Palgrave Macmillan.

Marcuse, Herbert. 1979. The Aesthetic Dimension: Toward a Critique of Marxist Aesthetics. London: Macmillan Education. https://doi.org/10.1007/978$\underline{1-349-04687-4}$

McKenzie, Jon. (2004) 2016. “The Liminal-Norm.” In The Performance Studies Reader, edited by Henry Bial and Sara Brady. Abingdon \& New York: Routledge.

Nail, Thomas. 2012. Returning to Revolution: Deleuze, Guattari and Zapatismo. Edinburgh: University Press. https://doi.org/10.3366/edinburgh/ $\underline{9780748655861.001 .0001}$

Politi. 2020. Accessed August 9. https://politi.dk/tildaekningsforbud.

Rahbek, Birgitte. 2020. "Dansk Kulturinstitut og Sisters Hope vil vise verden en anden vej ind i fremtiden: Vi lægger ud med at overtage en russisk folkeskole." Kulturmonitor, May 19. https://www.kulturmonitor.dk/dansk-kulturinstitut-og-sisters-hope-vil-vise-verden-en-anden-vej-ind-i-fremtiden-vilaegger-ud-med-at-overtage-en-russisk-folkeskole/

Ritzau. 2020. "Kulturminister sættes under pres for hjælpepakke til kulturen." Kristeligt Dagblad, March 26. https://www.kristeligt-dagblad.dk/kultur/kulturminister-saettes-under-pres-hjaelpepakke-til-kulturen

Rix, Lars. 2020. Kulturlivet igen sat bagerst i køen i genåbningsplan fra regeringen: "Det betyder mindst endnu en måned med blødende økonomi." Kulturmonitor, May 7. https://www.kulturmonitor.dk/kulturlivet-igen-sat-bagerst-i-koeen-i-genaabningsplan-fra-regeringen-det-betyder-mindst-endnuen-maaned-med-bloedende-oekonomi/

Schechner, Richard. (2013) 2017. Performance Studies - An Introduction, edited by Richard Schechner and Sara Brady, 3rd ed. London: Routledge. https://doi.org/10.4324/9780203125168

Schulze, Daniel. 2017. Authenticity in Contemporary Theatre and Performance: Make It Real, edited by Enoch Brater and Mark Taylor-Batty. London: Bloomsbury Publishing.

Senderovitz, Nana. 2018. "The Hope of The Sensuous - An exploration of The Critical Gaze and The Devoted Body.” Master's Thesis, Roskilde University.

Seulin, Christian, and Catalina Bronstein. 2019. On Freud's "The Uncanny." Milton: Taylor \& Francis Group. https://doi.org/10.4324/9780429287367

Sisters Academy/Projects. 2020. Accessed August 9. http://sistersacademy.dk/ projects/

Sisters Academy/Sounds. 2020. Accessed August 9. https://sistersacademy.dk/ sound/ 
Maja Ejrnes - What if Imagination Were Real?

Sisters Academy/Sweden. 2020. Accessed August 9. http://sistersacademy.dk/ about/inkonst/

Sisters Hope. 2019. "Sensuous Governing." 05.11 min. https://vimeo.com/ 344743308 .

Sjørslev, Inger. 2007. "Ritual, performance og socialitet - en introduktion.” In Scener for samvær: ritualer, performance og socialitet. Aarhus: Aarhus Universitetsforlag.

Sjørslev, Inger. 2012. "The Material Subject as Political: Style and Pointing in Public Performance.” Anthropological Theory 12 (2): 209-28. https:// doi.org/10.1177/1463499612457316

Skjoldager-Nielsen, Kim. 2011. "Who Am I Now, Who Am I Here?" In Spaces of Identity in the Performing Sphere, edited by Sibila Petlevski and Goran Pavlic. Zagreb: Fraktura.

Spiegel, Andrew D. 2011. "Categorical Difference versus Continuum: Rethinking Turner's Liminal-Liminoid Distinction.” Anthropology Southern Africa: Thinking Victor Turner's 'Liminality' from Southern Africa Today 34 (12): 11-20. https://doi.org/10.1080/23323256.2011.11500004

Teglbjærg, Camilla S. 2007. "Når musikken spiller sig selv: Jazzens flow og dens publikum." In Scener for samvær: ritualer, performance og socialitet, edited by Inger Sjørslev. Aarhus: Aarhus Universitetsforlag.

The Sensuous Society. 2020. Accessed August 9. http://sensuoussociety.org.

Turner, Victor. 1970. The Ritual Process: Stucture and Anti-Structure. New York: Cornell University Press.

Turner, Victor. 1974. "Liminal to Liminoid, in Play, Flow, and Ritual: An Essay in Comparative Symbology." Rice Institute Pamphlet-Rice University Studies $60(3)$.

Turner, Victor. 1980. "Social Dramas and Stories about Them." Critical Inquiry 7 (1): 141-68. https://doi.org/10.1086/448092

Tyler, Stephen A. 1986. "Post-Modern Ethnography." In Writing Culture: The Poetics and Politics of Ethnography, edited by George E. Marcus and James Clifford. Berkeley, Los Angeles and London: University of California

Wenger, Etienne. 1998. Communities of Practice: Learning, Meaning, and Identity. Cambridge: Cambridge University Press. https://doi.org/10.1017/ CBO9780511803932 